\title{
Context-Based Thematic Teaching Materials to Improve Elementary Students' Learning Achievements
}

\author{
Nur Fitriana Kusuma Wardani ${ }^{1 *}$, Sunardi ${ }^{2}$, Suharno ${ }^{3}$ \\ 1,2,3 Master of Educational Technology, Universitas Sebelas Maret, Surakarta \\ e-mail: nurfitriana.d0313005@gmail.com, nardi_ip@uns.ac.id, suharno.52@gmail.com
}

\begin{abstract}
Contextual learning connects the content of subject matters in the classroom with the context of students' daily lives. Elementary school learning is conducted using a thematic approach that integrates various learning contents into a theme. Thematic teaching materials in elementary schools depend on textbooks provided by the government and are limited in number. Therefore, this study aims to develop context-based thematic teaching materials to improve the learning achievements of elementary school students. In this study, the research and development method was used with the 4D model (Define, Design, Develop, and Disseminate). The product of development was validated by experts. Testing of the product was conducted twice, namely a small-group test with 8 elementary school students grade IV in SD 2 Guwo and a large-group $t$ to determine the effectiveness of the teaching material developed. The large-group test involved 32 students of grade IV in SD Negeri 2 Kadipaten as the experimental class and 30 students of grade IV in SD Negeri 2 Guwo as the control class. The results of this study indicate that there are significant differences in learning achievements between the experimental class and the control class. The experimental class using context-based thematic teaching materials has better performance than the control class using thematic textbooks. The context-based thematic teaching material that has been developed has been proven to be able to improve student achievement. The results of this study are expected to be a reference for teachers and policymakers to develop context-based thematic teaching materials.
\end{abstract}

Keywords: Contextual Teaching and Learning; Thematic Learning; Development of Teaching Materials

\section{Introduction}

The contextual approach connects the content of subject matters in the classroom with the context of the students' daily lives, so this approach can make learning more meaningful (Glynn \& Winter, 2004; Selvianiresa \& Prabawanto, 2017; Shidiq, 2016). The learning process with the contextual approach actively engages students in the learning process to find concepts learned by linking the material knowledge they have with their experiences in daily life (Johar, Agussalim, Ikhsan, \& Zaura, 2018; Kurniasari, Sukarmin, \& Sarwanto, 2018). Contextual learning emphasizes the students' acquisition of information through the process of critical thinking, inquiry, and problem solving (Glynn \& Winter, 2004).

The context in elementary schools is presented in the form of themes (Ain \& Rahutami, 2018). Thus, it becomes important to present the theme of learning following the context of students' daily lives (Min, 2012). To conduct context-based thematic learning, the teacher must have a good understanding of the subject matter, the ideas to be taught to students, and the best teaching method. The teacher must also know how students learn, what they already know from the subject matter, and many other factors to prepare for the learning process (Yuh-Tyng Chen, 2012).

Traditional learning applies separated learning, such as the division of subject units, chapters, and learning design elements. This section is usually delivered by elementary school teachers with separated and one-way learning methods or approaches. It is in contrast to thematic learning, which is done by connecting each chapter or subject with a theme. To determine this theme, the teacher can create a thematic teaching strategy based

\footnotetext{
* Corresponding author.

Received 31 December 2019; Accepted 3 June 2020; Available online 20 June 2020

(C) 2020 JPI. All Rights Reserved
} 
on students' life experiences; thus, learning will increase students' interests in learning (YuhTyng Chen, 2012).

Through the 2013 curriculum, Indonesia has implemented thematic learning in elementary schools (Yuliana, Wiryawan, \& Riyadi, 2018). The learning instruments of this curriculum have been prepared by the government, one of which is the student book. The research report states that books provided by the government are not enough to support the learning undertaken. In addition, in practice, government textbooks used by teachers and students in the learning process seem to have some weaknesses both in content and context. Teacher and student textbooks used in elementary schools contain only a few student worksheets where the material coverage is incomplete and less extensive. This makes the teacher and students have to find other learning resources or additional materials that can be used in the teaching and learning process (Ekowati \& Nenohai, 2016; Syafutri \& Soeharto, 2019; Yuliana et al., 2018).

The development of contextual teaching materials has been widely carried out, such as the development of contextual teaching materials for mathematics in senior high schools (Ekowati \& Nenohai, 2016; Hobri, Septiawati, \& Cahya Prihandoko, 2018; Mauliana, Ikhsan, \& Subianto, 2018), contextual science modules for junior high school students (Kurniasari et al., 2018), contextual teaching materials for the biology subject (Wahyuningtyas \& Wuryadi, 2018), video-based contextual learning media (Gayatri, Soegiyanto, \& Rintayati, 2018) and contextual teaching materials to improve problem-solving skills (Suryawati, Osman, \& Meerah, 2010).

In addition to contextual teaching materials, the research and development of thematic teaching materials have also been carried out, such as thematic learning in students with special needs (McCarthy, 2005), development of thematic teaching materials for mathematics lessons (Ekowati \& Nenohai, 2016), research on the effects of applying thematic learning (Nurlaela, Samani, Asto, \& Wibawa, 2018) and research on the effects of applying thematic learning videos (Yuh-Tyng Chen, 2012). Based on the literature review conducted on the development of contextual and thematic teaching materials, the development of context-based thematic teaching materials has not yet been found for elementary schools. Therefore, this study aims to develop context-based thematic teaching materials to improve the learning achievement of elementary school students. With the development of these teaching materials, it is expected to contribute to the novelty of teaching materials used in elementary schools.

\section{Method}

Thematic teaching materials compiled using the Contextual Teaching Learning (CTL) learning model serve as the basis of the learning model used to improve students' learning achievements on the theme of "Indahnya Keragaman di Negeriku" (Beautiful Diversity in My Country). The teaching material developed is in the form of student teaching materials. In this study, the research and development method was used with the 4D model. This model was developed by S. Thiagarajan (Thiagarajan, Semmel, \& Semmel, 1974), which consists of 4 main stages: define, design, develop, and disseminate.

Define stage includes the stage to find information by conducting interviews, observation, and distribution of needs analysis questionnaire to teachers and students about the facilities that support teaching and learning activities, infrastructure, teaching materials, and the state of students in teaching and learning activities in schools.

The design stage is the stage of project planning for the development of context-based thematic teaching materials. At this stage, activities are carried out to design development objectives, research schedules, specifications of teaching materials, and the structure of the materials used.

Develop stage includes the activities of making storyboards of context-based thematic teaching material products. Furthermore, the prototype of thematic teaching materials is validated by the linguist, material expert, media expert, and practitioners who are senior teachers. The validation results are then used at the product testing stage. There are two stages of product testing, namely a small-group test and a large-group test to determine 
product effectiveness. The small-group test involved 8 students of grade IV in SD Negeri 2 Guwo consisting of 4 students with high learning achievements and 4 students with low learning achievement. The large-group test was conducted on grade IV students of SDN 2 Kadipaten, Andong. To measure the effectiveness of the product being developed, the t-test of the post-test results between the control class and the experimental class at the largegroup test stage was conducted.

Limited dissemination was carried out by disseminating and promoting the final product of context-based thematic teaching materials to teachers of SDN 2 Kadipaten, Andong, Boyolali.

\section{Results and Discussion}

\subsection{Results}

The development of thematic teaching materials based on Contextual Teaching Learning (CTL) begins with reviewing Core Competencies (CC), Basic Competencies (BC), and syllabi. Learning objectives and indicators are arranged based on $\mathrm{BC}$, while the making of teaching material matrices is used to illustrate and design the material and activities contained in teaching materials. The stages contained in the thematic teaching material developed use the syntaxes of the Contextual Teaching Learning (CTL) model, namely constructivism, inquiry, questioning, learning community, modeling, reflection, and authentic assessment (Aqib, 2013). The learning matrix in context-based thematic teaching materials to improve students' learning achievements is presented in Table 1. The development of initial forms of context-based thematic teaching material is presented in Table 2 . The result of the validation is presented in Table 3 . The results of the small-group test are presented in table 4 and the effectiveness test results are presented in Table 5

Table 1. Learning Matrices on Context-Based Thematic Teaching Materials

\begin{tabular}{|c|c|c|}
\hline $\begin{array}{l}\text { CTL Model } \\
\text { Syntaxes }\end{array}$ & Teaching materials & Student Activities \\
\hline Constructivism & $\begin{array}{l}\text { Presenting phenomena used to } \\
\text { provide problems to be solved by } \\
\text { students. }\end{array}$ & $\begin{array}{l}\text { Getting to know the problem based on } \\
\text { the phenomena presented. }\end{array}$ \\
\hline Inquiry & $\begin{array}{l}\text { Presenting pictures to direct students } \\
\text { to design and observe problems. }\end{array}$ & Identifying the problem to be solved. \\
\hline Questioning & $\begin{array}{l}\text { Presenting instructions that lead } \\
\text { students to make arguments. Making } \\
\text { tentative arguments is done in groups } \\
\text { or individually. }\end{array}$ & Analyzing the problem. \\
\hline $\begin{array}{l}\text { Learning } \\
\text { Community }\end{array}$ & $\begin{array}{l}\text { Providing instructions for directing } \\
\text { students to discuss. }\end{array}$ & $\begin{array}{l}\text { Exchanging thoughts and ideas in } \\
\text { groups. }\end{array}$ \\
\hline & & $\begin{array}{l}\text { Presenting the results of their } \\
\text { arguments to be discussed together } \\
\text { with other groups. }\end{array}$ \\
\hline Modelling & $\begin{array}{l}\text { Presenting instructions to direct } \\
\text { students as an example of modeling, } \\
\text { namely reading texts and assignments } \\
\text { in teaching materials. }\end{array}$ & $\begin{array}{l}\text { Outstanding students come to the front } \\
\text { of the class as the role model for other } \\
\text { students. }\end{array}$ \\
\hline Reflection & $\begin{array}{l}\text { Presenting instructions to make notes } \\
\text { to review the subject matter that has } \\
\text { been learned in accordance with the } \\
\text { format presented in the teaching } \\
\text { material. }\end{array}$ & $\begin{array}{l}\text { Making notes of what has been learned } \\
\text { in accordance with the format in } \\
\text { teaching materials } \\
\text { Developing the knowledge already } \\
\text { obtained to produce new knowledge. }\end{array}$ \\
\hline $\begin{array}{l}\text { Authentic } \\
\text { Assessment }\end{array}$ & $\begin{array}{l}\text { Present evaluation questions to } \\
\text { measure students' abilities. }\end{array}$ & Working on evaluation questions. \\
\hline
\end{tabular}


Table 2. Development of Initial Forms of Context-Based Thematic Teaching Material

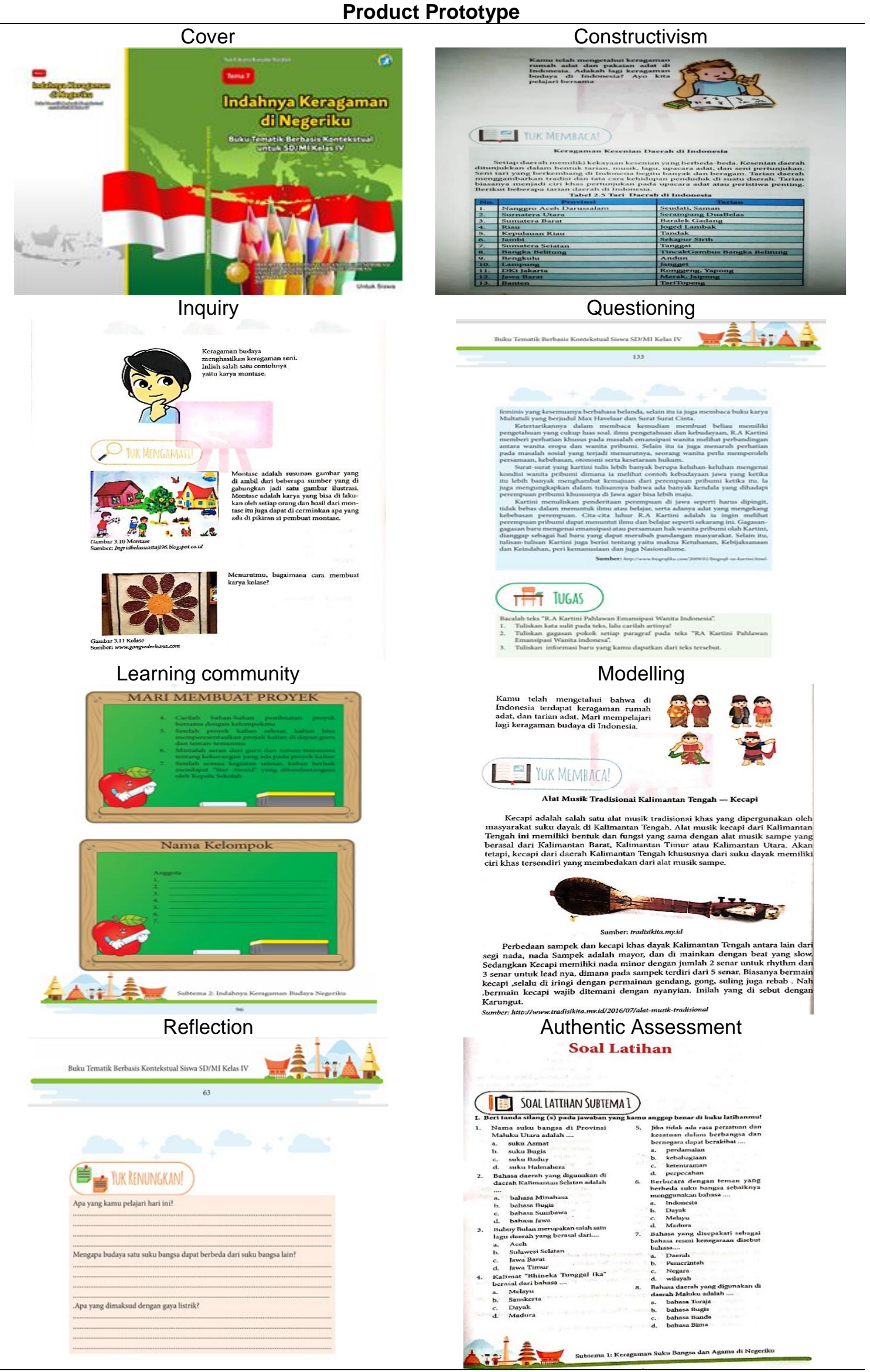


Table 3. The Results of Validation

\begin{tabular}{lccc}
\hline & Validators & Average score & Description \\
\hline Linguist & 3.85 & Very valid \\
Material Expert & 3.5 & Valid \\
Media Expert & 3.8 & Very valid \\
Educational Practitioners & 3.85 & Very valid \\
\hline
\end{tabular}

Table 4. Results of Small-group Test

\begin{tabular}{lcc}
\hline Students & Average Percentage (\%) & Qualification \\
\hline Student 1 & 85.42 & Very good \\
Student 2 & 93.75 & Very good \\
Student 3 & 100 & Very good \\
Student 4 & 93.75 & Very good \\
Student 5 & 94.53 & Very good \\
Student 6 & 97.92 & Very good \\
Student 7 & 93.75 & Very good \\
Student 8 & 97.92 & Very good \\
Average & 94.53 & Very good \\
\hline
\end{tabular}

Table 5. Effectiveness Test Results

\begin{tabular}{|c|c|c|}
\hline Tests & Results & Inference \\
\hline Normality test & $\begin{array}{c}\text { Experiment class } \\
0.200>0.05\end{array}$ & Normal \\
\hline (Kolmogorov Smirnov) & $\begin{array}{c}\text { Control class } \\
0.55>0.05\end{array}$ & Normal \\
\hline $\begin{array}{l}\text { Homogeneity test (Levene Statistic) } \\
\text { T-test (2-tailed) }\end{array}$ & $\begin{array}{l}\text { Sig. } 0.509>0.05 \\
\text { Sig. } 0.01<0.05\end{array}$ & $\begin{array}{l}\text { Homogenous } \\
\text { There is a sianificant difference }\end{array}$ \\
\hline
\end{tabular}

\subsection{Discussion}

Define stage is done to find out the problems and needs at school. Based on the analysis conducted by observing, distributing questionnaires to teachers and students, and also conducting a literature study, the main problem that arises is from the teaching material used because it is from the teaching material that the thematic learning begins. Teaching materials that have been prepared by the government and national themes make students unfamiliar with the themes being taught. Meanwhile, the thematic approach is a teaching method used by teachers to enable students to be actively involved in activities that focus on the topics students choose to study (Piazza, Scott, \& Carver, 1994).

At the development stage, context-based thematic teaching materials were developed. The learning instruments compiled are the lesson plan, student worksheets, questions to measure learning achievement aspects of knowledge, and observation sheets to measure the learning achievements of the skill aspect. The assessment of cognitive and affective aspects is in line with the demands of the Indonesian curriculum and has been carried out by other researchers such as research on the effects of constructive approaches on students' cognitive and affective abilities (Urbani et al., 2017; Wu \& Tsai, 2005) Table 3 shows the results of the initial development of context-based thematic teaching material products.

After the context-based thematic teaching material prototype has been developed, it is tested and validated by expert judgment. The validation was conducted to find out responses and assessments in the form of inputs, criticism, and suggestions from the linguist, media expert, material expert, and practitioners (Scantlebury, Boone, Kahle, \& Fraser, 2001; Zulfaneti, Rismen, \& Suryani, 2016). This validation was done by providing an assessment questionnaire containing the feasibility indicators for each part. The validator gives a score of 1 if the product quality does not match the indicator and 4 if it does. The results of the validation of context-based thematic teaching materials by expert validators are presented in Table 4. All validators state that what was developed is valid. 
After going through the validation stage, the product is then tested through two stages: the small-group test and the large-group test. A small group test was conducted on 8 students who were selected specifically based on the high cognitive level of 4 students and the low cognitive level of 4 students. The difference in various levels of cognitive mastery in selecting the students for the small-group test aims to get the results of students' assessments that can represent all students who have diverse abilities in the field. The results of the small-group test on teaching materials developed are presented in Table 5. All students at this test stage stated that the products developed were very good.

The large-group test is conducted to determine the effectiveness of context-based thematic teaching materials to improve students' learning achievements. The effectiveness test uses the experimental design with two schools, namely, grade IV of SDN 2 Kadipaten as the experimental class using context-based thematic teaching materials and grade IV of SDN 2 Guwo as the control class using textbooks from school. The experimental class and the control class selected to have the same characteristics. To measure the learning achievements of both classes, a post-test was conducted. The number of students in the experimental class was 32 and in the control class was 30 . The learning activities were carried out in 18 meetings with an allocation of 118 lesson hours.

The effectiveness of context-based thematic teaching materials was analyzed using SPSS 20 which was preceded by prerequisite tests, normality and homogeneity tests, as well as a T-test to determine the presence or absence of post-test score differences in the experimental class and the control class. The results of the analysis can be seen in Table 6 .

The results of the effectiveness test (2-tailed t-test) of context-based thematic teaching materials using SPSS 20 shows a significant difference in the learning achievements between the experimental class and the control class. In addition, based on the results of the descriptive analysis of the students' achievements in the skill aspect, the average post-test score of the experimental class was 82.03 and the control class was 74.33. The descriptive analysis results show that the average score of students in the experimental class is higher than in the control class, which means that the application of context-based thematic teaching materials in the learning process effectively improves students' learning achievements. The results of this study support various studies on the development of thematic and contextual learning media in elementary schools such as the use of thematic on environment-based mathematics modules (Ain \& Rahutami, 2018; Ekowati \& Nenohai, 2016), and the use of contextual approaches to teaching science in elementary schools (Glynn \& Winter, 2004; Milner, Templin, \& Czerniak, 2011)

The final product of context-based thematic teaching materials that had passed the stages of repeated tests and revisions was then disseminated to the teachers of SDN 2 Kadipaten in Andong Boyolali. This dissemination is done so that developed products can be used by the teachers as an alternative and additional teaching materials that can improve students' achievements in grade IV. This dissemination is important to do so that the media that have been developed can be known and used by other elementary school teachers (Khatri et al., 2017; Yuliana et al., 2018). The more users of the product being developed, the more students there can be improved cognitive and affective abilities, besides that there will be a lot of input for researchers to improve the product in the future.

Thematic learning integrates knowledge from various disciplines and encourages students to explore topics in-depth, read various sources, and get involved in various activities (Gardner, Wissick, Schweder, \& Canter, 2003). Thematic learning offers a way to integrate students' interests with core skills to motivate them to do academic activities they do not like. Thematic units also provide opportunities for collaboration between special and general education teachers to examine, adapt, and integrate basic skills with a theme (Gardner et al., 2003). Learning that is in line with daily life and accommodates a variety of student skills is needed in this $21^{\text {st }}$-century education (Shidiq \& Yamtinah, 2019).

The basic competency chosen in this study is the BC of civics education, identifying various forms of ethnic, social and cultural diversity in Indonesia, which is bound by unity and integrity; BC of social studies, identifying social, economic, cultural, ethnic and religious diversity in the province as the identity of the Indonesian nation; BC of science, identifying 
various forces, including muscular, electric, magnetic, gravitational and frictional forces; BC of Indonesian Language, exploring new knowledge contained in nonfiction texts; and BC of cultural art, knowing the tempo and the pitch. By combining several subjects into one theme, it is expected to make learning more meaningful. It is also hoped that this will reduce student misconceptions (Yamtinah et al., 2019)

Research on applying thematic learning is done not only in Indonesia but also in many countries reporting on the successful application of this type of learning. Among them are the application of thematic learning by integrating technology in Japan (Wepner, 1993), research on the effectiveness of thematic learning in New Zealand (Bitchener \& Turner, 2011), and the application of thematic learning in various other countries (Aggelakos, 2007; Gardner et al., 2003; Lung, 2012; McCauley, 1966; Resor \& Gandy, 2013; Sheppard, 2012; Trifonoff, 1995; White, 2014; Willey, 2006).

In addition, the results of the research conducted by experts provide an overview of effective thematic learning, such as integrated thematic learning to improve the quality of learning (Lipson, Valencia, Wixson, \& Peters, 1993), research on thematic learning with inquiry to improve literacy (Shanahan, 1997), application of thematic maps in elementary schools (Michaelidou, Nakos, \& Filippakopoulou, 2007; Trifonoff, 1995) and research on the effects of thematic learning, direct science teaching with a textbook approach for students (McCarthy, 2005). Every research that has been done has its contribution to novelty and characteristics. Likewise, the research on the development of context-based thematic teaching materials conducted has its distinctive characteristics. First, the thematic teaching material uses the steps of a Contextual Teaching Learning (CTL) model in its delivery, consisting of 7 steps of constructivism, inquiry, questioning, learning community, modeling, reflection, and authentic assessment. Second, context-based thematic teaching materials were developed to improve students' learning achievements on the theme of "Beautiful Diversity in my Country". Third, Context-based thematic teaching materials developed are the manuals for students to improve their achievements. These characteristics make the development conducted differently from the others and can add the novelty of the research and development carried out.

\section{Conclusion}

The results showed that context-based thematic teaching materials were valid. In addition, the results of the effectiveness test showed that context-based thematic teaching materials have been effective in improving student learning achievement. Context-based thematic teaching materials developed have a novelty at the learning stages that are in it, namely: constructivism, inquiry, questioning, learning community, modeling, reflection, and authentic assessment. This learning phase is a differentiator between research conducted with other research. The teaching material developed is expected to be a reference for teachers and policymakers to develop context-based thematic teaching materials for use in elementary schools.

\section{References}

Aggelakos, C. (2007). The Cross-Thematic Approach and the 'New' Curricula of Greek Compulsory Education: Review of an Incompatible Relationship. Policy Futures in Education, 5(4), 460-467. https://doi.org/10.2304/pfie.2007.5.4.460

Ain, N., \& Rahutami, R. (2018). Theme network in thematic learning in elementary school. Journal of Physics: Conference Series, 1013(1). https://doi.org/10.1088/17426596/1013/1/012065

Aqib, Z. (2013). Model-model, media, dan strategi pembelajaran kontekstual (inovatif). Bandung: Yrama Widya.

Bitchener, J., \& Turner, E. (2011). Assessing the effectiveness of one approach to the teaching of thematic unit construction of literature reviews. Assessing Writing, 16(2), 123-136. https://doi.org/10.1016/j.asw.2011.02.002 
Ekowati, C. K., \& Nenohai, J. M. H. (2016). The Development of Thematic Mathematics Book Based on Environment with a Realistic Approach to Implant the Attitude of Caring about Environment at Students of Elementary School Grade One in Kupang. $\begin{array}{llll}\text { International Journal of Higher Education, } & 6(1),\end{array}$ https://doi.org/10.5430/ijhe.v6n1p112

Gardner, J. E., Wissick, C. A., Schweder, W., \& Canter, L. S. (2003). Enhancing interdisciplinary instruction in general and special education: Thematic units and technology. Remidial and Special Education, 24(3), 161-172.

Gayatri, T., Soegiyanto, H., \& Rintayati, P. (2018). Development of Contextual Teaching Learning-Based Audio Visual Adobe Flash Media to Improve Critical Thinking Ability of Geography Learning at Senior High School. IOP Conference Series: Earth and Environmental Science, 145(1). https://doi.org/10.1088/1755-1315/145/1/012004

Glynn, S. N., \& Winter, L. K. (2004). Contextual Teaching and Learning of Science in Elementary Schools. Journal of Elementary Science Education, 16(2), 51-63.

Hobri, Septiawati, I., \& Cahya Prihandoko, A. (2018). High-order thinking skill in contextual teaching and learning of mathematics based on lesson study for learning community. $\begin{array}{llll}\text { International Journal of Engineering \& Technology, 7(3), } 1576 . & \text {. }\end{array}$ https://doi.org/10.14419/ijet.v7i3.12110

Johar, R., Agussalim, Ikhsan, M., \& Zaura, B. (2018). The development of learning materials using contextual teaching learning (CTL) approach oriented on the character education. Journal of Physics: Conference Series, 1088, 0-6. https://doi.org/10.1088/1742-6596/1088/1/012039

Khatri, R., Henderson, C., Cole, R., Froyd, J. E., Friedrichsen, D., \& Stanford, C. (2017). Characteristics of well-propagated teaching innovations in undergraduate STEM. International Journal of STEM Education, 4(1). https://doi.org/10.1186/s40594-0170056-5

Kurniasari, H., Sukarmin, \& Sarwanto. (2018). Development of contextual teaching and learning based science module for junior high school for increasing creativity of students. Journal of Physics: Conference Series, 983(1). https://doi.org/10.1088/17426596/983/1/012035

Lipson, M. Y., Valencia, S. W., Wixson, K. K., \& Peters, C. W. (1993). Integration and Thematic Teaching: Integration to Improve Teaching and Learning. Language Arts, $70(4), 252-263$.

Lung, M. (2012). A Thematic Approach: Making a Biology Course Relevant \& ProcessOriented. The American Biology Teacher, 61(1), 18-22. https://doi.org/10.2307/4450604

Mauliana, Ikhsan, M., \& Subianto, M. (2018). Development of Learning Tool with Contextual Teaching and Learning (CTL) Approach to Improve Student Mathematical Connection Ability. Journal of Physics: Conference Series, 1088, 4-9. https://doi.org/10.1088/1742-6596/1088/1/012012

McCarthy, C. B. (2005). Effects of thematic-based, hands-on science teaching versus a textbook approach for students with disabilities. Journal of Research in Science Teaching, 42(3), 245-263. https://doi.org/10.1002/tea.20057

McCauley, M. J. (1966). A thematic approach to physics. Science Education, 50(4), 301308. https://doi.org/10.1002/sce.3730500403

Michaelidou, E., Nakos, B., \& Filippakopoulou, V. (2007). The Ability of Elementary School Children to Analyse General Reference and Thematic Maps. Cartographica: The International Journal for Geographic Information and Geovisualization, 39(4), 65-88. https://doi.org/10.3138/k63j-1260-8416-863w

Milner, A. R., Templin, M. A., \& Czerniak, C. M. (2011). Elementary Science Students' Motivation and Learning Strategy Use: Constructivist Classroom Contextual Factors in a Life Science Laboratory and a Traditional Classroom. Journal of Science Teacher Education, 22(2), 151-170. https://doi.org/10.1007/s10972-010-9200-5 
Min, K. C. (2012). Teachers ' Understanding and Practice towards Thematic Approach in Teaching Integrated Living Skills ( ILS ) in Malaysia. International Journal of Humanities and Social Science, 2(23), 273-281.

Nurlaela, L., Samani, M., Asto, I. G. P., \& Wibawa, S. C. (2018). The effect of thematic learning model, learning style, and reading ability on the students' learning outcomes. IOP Conference Series: Materials Science and Engineering, 296(1). https://doi.org/10.1088/1757-899X/296/1/012039

Piazza, J. A., Scott, M. M., \& Carver, E. C. (1994). Thematic Webbing and the Curriculum Standards in The Primary Grades. The Arithmetic Teacher, 41(6), 294-298.

Resor, C., \& Gandy, S. K. (2013). Dreaming of a Better Life: Utopia as a Focus for Thematic, Interdisciplinary Instruction. The Clearing House: A Journal of Educational Strategies, Issues and ldeas, 87(1), 1-8. https://doi.org/10.1080/00098655.2013.813432

Scantlebury, K., Boone, W., Kahle, J. B., \& Fraser, B. J. (2001). Design, validation, and use of an evaluation instrument for monitoring systemic reform. Journal of Research in Science Teaching, 38(6), 646-662. https://doi.org/10.1002/tea.1024

Selvianiresa, D., \& Prabawanto, S. (2017). Contextual Teaching and Learning Approach of Mathematics in Primary Schools. Journal of Physics: Conference Series, 895(1). https://doi.org/10.1088/1742-6596/895/1/012171

Shanahan, T. (1997). Reading-Writing Relationships, Thematic Units, Inquiry Learning In Pursuit of Effective Integrated Literacy Instruction. The Reading Teacher, 51(1), 1219.

Sheppard, N. (2012). A Thematic Approach to Concerns of the Future. Change: The Magazine of Higher Learning, 10(7), 30-33. https://doi.org/10.1080/00091383.1978.10569479

Shidiq, A. S. (2016). Pembelajaran Sains Kimia Berbasis Etnosains Untuk Meningkatkan Minat Dan Prestasi Belajar Siswa. In Seminar Nasional Kimia dan Pendidikan Kimia VIII (pp. 227-236). Surakarta: Program Studi Pendidikan FKIP UNS.

Shidiq, A. S., \& Yamtinah, S. (2019). Pre-service chemistry teachers' attitudes and attributes toward the twenty-first century skills. Journal of Physics: Conference Series, 1157(042014), 1-8. https://doi.org/10.1088/1742-6596/1157/4/042014

Suryawati, E., Osman, K., \& Meerah, T. S. M. (2010). The effectiveness of RANGKA contextual teaching and learning on student's problem solving skills and scientific attitude. Procedia - Social and Behavioral Sciences, 9, 1717-1721. https://doi.org/10.1016/j.sbspro.2010.12.389

Syafutri, R., \& Soeharto. (2019). Movable Book Development To Improve Students' Science Process Skills. Jurnal Pendidikan Indonesia, 8(1), 141-150. https://doi.org/10.23887/jpi-undiksha.v8i1.15640

Thiagarajan, S., Semmel, D. S., \& Semmel, M. I. (1974). Instructional development for training teachers of exceptional children: A sourcebook. Center for Innovation in Teaching the Handicapped. Bloomington: Indiana University. https://doi.org/10.1016/0022-4405(76)90066-2

Trifonoff, K. M. (1995). Going beyond location: Thematic maps in the early elementary grades. Journal of Geography, 94(2), 368-374. https://doi.org/10.1080/00221349508979745

Urbani, J. J. M., Truesdell, E., Urbani, J. J. M., Roshandel, S., Michaels, R., Truesdell, E., ... Truesdell, E. (2017). Assessment and Teaching of 21st Century Skills. Educacion Quimica, 1(1), 1709-1716. https://doi.org/10.1016/j.sbspro.2009.01.303

Wahyuningtyas, R. S., \& Wuryadi, W. (2018). The influence of contextual teaching and learning $(\mathrm{CTL})$ on critical thinking ability and conceptual understanding of skeletal

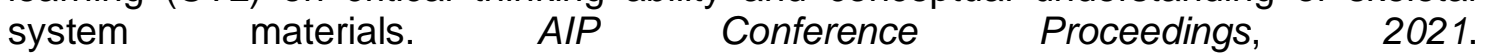
https://doi.org/10.1063/1.5062828

Wepner, S. B. (1993). Technology Links to Literacy: Technology and Thematic Units: An Elementary Example on Japan. The Reading Teacher, 46(5), 442-445. 
White, R. M. (2014). How Thematic Teaching Can Transform History Instruction. The Clearing House: A Journal of Educational Strategies, Issues and Ideas, 68(3), 160162. https://doi.org/10.1080/00098655.1995.9957220

Willey, W. (2006). A Thematic Approach to the Teaching of English. The English Journal, 51(9), 643. https://doi.org/10.2307/810258

Wu, Y. T., \& Tsai, C. C. (2005). Effects of constructivist-oriented instruction on elementary school students' cognitive structures. Journal of Biological Education, 39(3), 113-119. https://doi.org/10.1080/00219266.2005.9655977

Yamtinah, S., Indriyanti, N. Y., Saputro, S., Mulyani, S., Ulfa, M., Mahardiani, L., ... Shidiq, A. S. (2019). The identification and analysis of students ' misconception in chemical equilibrium using computerized two-tier multiple-choice instrument. Journal of Physics: Conference Series, 1157 (2019(042015), 1-7. https://doi.org/10.1088/17426596/1157/4/042015

Yuh-Tyng Chen. (2012). The effect of thematic video-based instruction on learning and motivation in e-learning. International Journal of the Physical Sciences, 7(6), 957-965. https://doi.org/10.5897/ijps 11.1788

Yuliana, M., Wiryawan, S. A., \& Riyadi. (2018). The development of thematic materials using project based learning for elementary school. Journal of Physics: Conference Series, 1022(1). https://doi.org/10.1088/1742-6596/1022/1/012018

Zulfaneti, Rismen, S., \& Suryani, M. (2016). Validity analysis of development lesson plan and student worksheet based realistic mathematics education. AIP Conference Proceedings, 1707. https://doi.org/10.1063/1.4940857 